\title{
PENGARUH PENGGUNAAN INTERNET TERHADAP LITERASI KELUARGA
}

\author{
Tarma $^{1} \&$ Maya Oktaviani ${ }^{2}$ \\ e-mail: tarmasae@gmail.com ${ }^{1} \&$ maya.oktaviani@unj.ac.id ${ }^{2}$ \\ Pendidikan Kesejahteraan Keluarga Universitas Negeri Jakarta \\ Jalan Rawamangun Muka, RT.11/RW.14, Rawamangun, Pulo Gadung, \\ Kota Jakarta Timur, Daerah Khusus Ibukota Jakarta 13220
}

\begin{abstract}
Abstrak: Penelitian ini bertujuan untuk menentukan pengaruh penggunaan internet terhadap literasi keluarga. Penelitian ini dilaksanakan dengan menggunakan metode survei kepada 100 keluarga di daerah Candi Batujaya, Karawang. Instrumen non-tes dalam bentuk kuesioner yang terdiri atas 50 pernyataan dengan menggunakan skala frekuensi (4 skala) yaitu selalu, sering, jarang, dan tidak pernah. Data dianalisis mengunakan t-test. Sebelum menganalisis data, tes normalitas dan homogenitas dilakukan untuk mendapatkan asumsi normal dan homogen. Hasil penelitian menunjukkan bahwa penggunaan internet mempengaruhi literasi keluarga meskipun relatif kecil (6,15\%). Monitoring kolaboratif menghasilkan skor rata-rata tertinggi (2.89 dari 4.00), sementara keterlibatan keluarga menghasilkan skor rata-rata terendah (2.40 dari 4.00).
\end{abstract}

Kata-kata Kunci: Penggunaan internet, keluarga, literasi keluarga

\section{THE EFFECT OF INTERNET USAGE TOWARDS FAMILY LITERACY}

\begin{abstract}
This research aims to determine the effect of internet usage on family literacy. The study was conducted with a survey method of 100 families in the area of Candi Batujaya, Karawang. A non-test instrument in the form of a family literacy questionnaire consisting of 50 items with a verbal frequency scale (4 scales) of always, often, rarely, and never was used. Data were analyzed using the t-test. Before analyzing the data, normality and homogeneity tests were performed to meet normal and homogeneous assumptions. The results showed that internet usage influenced family literacy even though relatively small (6.15\%). Collaborative monitoring was the highest means score (2.89 out of 4.00), while parent involvement was the lowest means score (2.40 out of 4.00).
\end{abstract}

Keywords: Internet usage, family, family literacy

\section{PENDAHULUAN}

Indonesia merupakan negara kepulauan yang terdiri dari beragam suku bangsa. Hal tersebut menghasilkan beragam adat, kebiasaan, bahasa, budaya, agama, dan kepercayaan. Setiap warga negara harus memiliki kesadaran atas keberagaman bangsanya. Tanpa adanya kesadaran tersebut, bisa muncul konflik di kalangan masyarakat. Masyarakat yang tidak memahami keberagaman yang dimiliki oleh bangsanya dapat dengan mudah dipecah belah dan diadu domba. Oleh karena itu, kemampuan dalam memahami keberagaman, menerima perbedaan, mampu beradaptasi, dan menyikapi keberagaman secara bijaksana menjadi sesuatu yang wajib dimiliki oleh individu. Literasi menjadi kecakapan yang harus dimiliki oleh masyarakat.

Literasi dapat dimulai sejak dini dan dalam lingkungan yang kecil. Salah satunya dapat melalui keluarga. Peran keluarga dapat menentukan masa 
depan anak bangsa. Pembiasaan kegiatan membaca di lingkungan keluarga, dapat meningkatkan literasi dalam keluarga tersebut. Sayangnya, literasi di Indonesia masih rendah. Data hasil survey yang dilakukan oleh PISA pada tahun 2012 menunjukkan bahwa Indonesia menempati posisi ke-57 dari tota 65 negara. Hal ini menunjukkan bahwa kesadaran akan kebutuhan literasi bagi masyarakat Indonesia masih sangat rendah. Terdapat beberapa faktor yang menjadi penyebab rendahnya literasi. Fadriyani (2010) menyebutkan bahwa intelegensi, kesehatan fisik, kondisi fisik, jenis kelamin, lingkungan, perkembangan motorik, perbedaan status sosial, dan keterlibatan orang tua merupakan beberapa hal yang mempengaruhi literasi.

Penelitian sebelumnya yang dilakukan oleh Deborah (2006) menunjukkan bahwa terdapat hubungan yang kuat antara ketertarikan anak dalam membaca dengan cara ibu dalam membacakan buku. Penelitian lain yang dilakukan oleh Laurent (2005) menghasilkan kesimpulan bahwa kegiatan menyenangkan di rumah yang diciptakan oleh orang tua dan disertai dengan usaha orang tua akan memberikan efek yang menyenangkan dalam mengembangkan literasi anak. Berdasarkan hal tersebut dapat diketahui bahwa faktor literasi keluarga menjadi salah satu penyebab rendahnya literasi. Literasi keluarga merupakan upaya yang dilakukan orang tua dalam rangka mengembangkan kemampuan literasi anaknya yang mencakup literasi baca tulis, literasi informasi, dan jenis literasi lainnya.

Keberhasilan literasi keluarga tidak terlepas dari faktor eksternal seperti penggunaan internet dalam mengakses informasi dan bahan bacaan lainnya. Penggunaan internet yang bertanggung jawab akan memberikan dampak positif bagi penggunanya. Adanya internet memudahkan seseorang untuk mengakses informasi dan menggali pengetahuan lebih dalam. Hasil penelitian Soenhaji (dalam Setiyani, 2010) menyimpulkan bahwa penggunaan internet bermanfaat untuk keberhasilan belajar mahasiswa. Sayangnya, masih terdapat orang tua yang tidak mengizinkan anaknya menggunakan internet. Beberapa orang tua di wilayah Candi Batujaya, Karawang, tidak mengizinkan anak-anak mereka mengakses internet. Selain itu, sebagian besar orang tua juga tidak menyediakan buku dan bahan bacaan lainnya yang dapat dimanfaatkan oleh anak-anaknya agar memiliki kemampuan literasi yang baik.

Penggunaan internet dalam kegiatan pembelajaran berkaitan dengan motif kognitif, yaitu sebuah usaha untuk mendapatkan atau mengumpulkan pengetahuan. Banyak informasi yang bisa didapatkan dengan mengakses internet. Internet dapat dijadikan sebagai sumber belajar dan bacaan. Hasil penelitian Pibriana dan Ricoida (2017) menyimpulkan bahwa kemudahan memperoleh informasi dari internet dapat menumbuhkan minat belajar seseorang. Minat seseorang dalam belajar akan menumbuhkan kebiasaan literasi dalam keluarganya.

Berdasarkan hal tersebut, maka perlu adanya penelitian mengenai apakah terdapat pengaruh penggunaan internet terhadap literasi keluarga. Tujuan penelitian ini adalah untuk mengetahui ada atau tidaknya pengaruh penggunaan internet terhadap literasi keluarga.

\section{Kajian Teoritik}

Literasi keluarga merupakan kegiatan literasi dalam keluarga (Desmon \& Elfert, 2008) yang mencakup cara-cara orang belajar dan menggunakan literasi di dalam kehidupan keluarga (Purcell-Gates, 2007) dan masyarakat, serta cara orang tua untuk membantu anaknya dalam belajar literasi (Crawford \& Zygouris-Coe, 2006). Literasi keluarga merupakan aktivitas literasi yang dilakukan dalam lingkungan keluarga, di mana anggota keluarga yang lebih tua melibatkan anak-anak dalam aktivitas literasi (Hannon, 1999). Literasi keluarga juga menekankan pada kegiatan bersama antara orang tua dan anak di mana orang dewasa sebagai model fungsi literasi (Taylor, 1988; Wasik, 2004). Berdasarkan pendapat beberapa pakar dapat disimpulkan bahwa literasi keluarga merupakan upaya yang dilakukan orang tua dalam rangka mengembangkan kemampuan literasi anaknya yang mencakup literasi baca tulis, literasi informasi, dan jenis literasi lainnya.

Nickse, et al (1994) menyatakan beberapa prinsip literasi keluarga yang meliputi 1) orang tua membacakan buku kepada anak, 2) orang tua menanyakan pekerjaan rumah dari sekolah kepada anak, 3) orang tua memperhatikan pekerjaan rumah anaknya, 4) orang tua membimbing anak dalam mengerjakan pekerjaan rumah, 5) orang tua menulis catatan dan pesan untuk anaknya, 6) orang tua melalukan permainan kata dengan anak, 7) orang tua menonton televisi bersama anak dan mendiskusikan tayangan televisi setelah menontonnya, 8) orang tua membeli buku bersama anak atau untuk anak, 9) orang tua membantu anak untuk menulis surat, dan 10) orang tua menanyakan kepada anak tentang sekolah dan kegiatan membaca. Sedangkan prinsip literasi keluarga menurut Brooks, et al (2008) meliputi 1) kegiatan menyimak untuk mengajar, 2) kegiatan 
dengan model pohon, 3) pembelajaran dalam keluarga bersifat inklusif, dan 4) kegiatan yang mengubah keluarga agar mengubah tingkat literasi.

Terdapat beberapa dimensi literasi keluarga menurut Scholastic (Kuo, 2016) yaitu literasi sejak dini, keterlibatan orang tua, akses terhadap buku, belajar secara luas, dan kerjasama pemantauan. Literasi sejak dini dipercaya menjadi dasar perkembangan literasi seorang anak. Anak-anak yang berada dalam lingkungan terpelajar sejak lahir akan terpapar literasi yang dapat meningkatkan motivasi membacanya. Keterlibatan keluarga merupakan prediktor penting dari keberhasilan akademik dan hubungan sosial anakanak. Anak-anak yang mengetahui adanya keperdulian dari orang tua pada kehidupan sekolahnya, akan berusaha lebih giat di sekolah. Kesempatan belajar tambahan yang berkualitas meningkatkan hasil belajar anak-anak dan interaksi sosial dengan teman sebaya.

Indikator pengukuran literasi keluarga dikembangkan oleh beberapa ahli. Salah satunya adalah Quick et al (2011) yang mengembangkan indikator pengukuran literasi keluarga menjadi lima indikator, yaitu membaca untuk anak, melakukan kunjungan bulanan ke perpustakaan, menghadiri acara sekolah, menjadi sukarelawan di ruang kelas, dan berpartisipasi dalam komite sekolah.

Kim (2010) memiliki sembilan indikator yang agak berbeda. Kesembilan indikator tersebut adalah seberapa sering orang tua mengajarkan literasi kepada anak, seberapa sering anggota keluarga membaca buku dan majalah, seberapa sering anggota keluarga membacakan buku untuk anak, seberapa sering anggota keluarga membacakan buku dengan anak, seberapa sering anak membaca buku di rumah, seberapa sering anggota keluarga membantu anak menyelesaikan pekerjaan rumah, seberapa sering anggota keluarga mengunjungi perpustakaan atau toko buku dengan anak, berapa banyak buku anakanak yang dimiliki, dan berapa banyak buku yang dibaca anak.

Keberhasilan literasi keluarga tidak terlepas dari faktor eksternal seperti penggunaan internet dalam mengakses informasi dan bahan bacaan lainnya. Internet adalah suatu alat yang memungkinkan individu untuk terhubung dengan individu lainnya untuk berkomunikasi, menerima, dan menyebarkan informasi (Pibriana \& Ricoida, 2017). Internet menghubungkan jaringan komputer dari berbagai pihak secara langsung dan cepat (Turban, Rainer, \& Potter, dalam Sherlyanita \& Rakhmawatii, 2016). Internet hingga saat ini sudah menjadi salah satu platform sebagai sumber belajar dan bahan ajar.
Individu dapat mengakses internet secara langsung dan di manapun, termasuk ketika berada di lingkungan tempat tinggal. Salah satu fungsi internet yaitu sebagai media edukasi, sehingga pemanfaatan internet dapat digunakan untuk membiasakan kegiatan literasi di lingkungan keluarga.

\section{METODE PENELITIAN}

Penelitian ini dilakukan di Desa Segaran, Kecamatan Batujaya, Kabupaten Karawang, Provinsi Jawa Barat. Penelitian dilakukan menggunakan metode survey. Populasi dalam penelitian ini adalah keluarga yang memiliki anak usia sekolah dengan jumlah 2.500 orang. Sampel dipilih dengan teknik cluster sampling sebanyak 100 keluarga. Data diperoleh dari salah satu anggota keluarga. Data dikumpulkan melalui kuesioner literasi keluarga. Terdapat lima dimensi yang digunakan dalam kuesioner tersebut, yaitu literasi sejak dini, keterlibatan orang tua, akses terhadap buku, belajar secara luas, dan kerjasama pemantauan (Scholastic dalam Kuo, 2016).

Instrumen tersebut disusun menggunakan skala frekuensi verbal (4 skala) yang terdiri dari selalu, sering, jarang, dan tidak pernah. Instrumen tersebut divalidasi kepada ahli terlebih dahulu sebelum akhirnya digunakan untuk pengambilan data ke lapangan. Pada akhirnya, terdapat 50 butir pernyataan yang valid. Selanjutnya data dianalisis menggunakan uji perbedaan dua rata-rata untuk sampel bebas (uji-t). Sebelum menganalisis data, dilakukan uji asumsi yaitu normalitas dan homogenitas. Uji normalitas dilakukan untuk mengetahui apakah data yang dianalisis berasal dari populasi yang berdistribusi normal atau tidak. Sedangkan uji homogenitas dilakukan untuk mengetahui apakah kedua kelompok yang diteliti memiliki varians yang sama/homogen. Uji normalitas dilakukan dengan uji Lilliefors, sedangkan uji homogenitas menggunakan uji Bartlett.

\section{HASIL DAN PEMBAHASAN}

\section{Hasil Dan Pembahasan}

Data hasil penelitian dianalisis secara deskriptif terlebih dahulu. Data Weight Mean Score (WMS) untuk setiap dimensi dalam literasi keluarga seperti terlihat pada gambar 1. Berdasarkan gambar tersebut, dapat disimpulkan bahwa WMS paling tinggi terdapat pada dimensi kerjasama pemantauan yaitu sebesar 2,89 sedangkan WMS paling rendah terdapat pada dimensi keterlibatan orang tua dengan nilai sebesar 2,40. 


\section{Dimensi Literasi Keluarga}

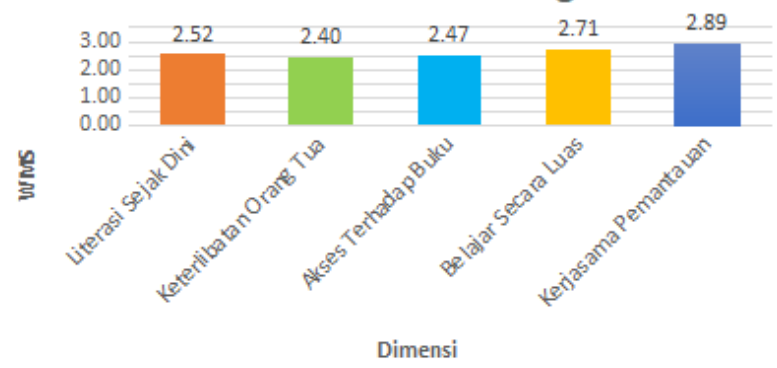

Gambar 1. Weight Mean Score untuk Tiap Dimensi dalam Literasi Keluarga

Data literasi keluarga dari 100 orang responden memperoleh hasil bahwa terdapat 2 orang yang memiliki kemampuan literasi keluarga dalam kategori sangat rendah, 17 orang yang memiliki kemampuan literasi keluarga dalam kategori rendah, 67 orang yang memiliki kemampuan literasi keluarga dalam kategori sedang, dan 14 orang yang memiliki kemampuan literasi keluarga dalam kategori tinggi. Dengan demikian tidak ada responden yang memiliki kemampuan literasi keluarga dalam kategori sangat tinggi. Dari 100 responden, diketahui nilai kemampuan literasi terendahnya adalah 63, sementara yang tertinggi adalah 158. Data tersebut memiliki rata-rata 114,66 , simpangan baku sebesar 18,529, dan variansi sebesar 343,318 .

\section{Kemampuan Literasi Keluarga}

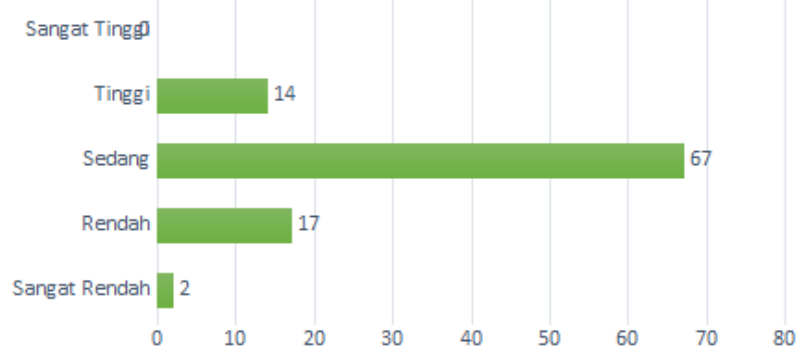

Gambar 2. Kemampuan Literasi Keluarga untuk Setiap Kategori

Responden dibedakan menjadi dua kelompok. Kelompok pertama adalah kelompok keluarga yang menggunakan internet dan kelompok kedua adalah kelompok keluarga yang tidak menggunakan internet. Terdapat 34 keluarga yang tergolong ke dalam kelompok pertama dan 66 keluarga yang tergolong ke kelompok kedua. Pada kelompok pertama, nilai tertinggi yang diperoleh adalah 158 , sedangkan nilai terendahnya 89 . Kelompok kedua memperoleh nilai tertinggi 152 dan nilai terendah 63. Selanjutnya data yang dihasilkan dari pengisian kuesioner dianalisis.
Tabel 1.

Statistika Deskriptif untuk Data Literasi Keluarga

\begin{tabular}{lccc}
\hline Penggunaan Internet & Mean & $\mathbf{N}$ & $\begin{array}{c}\text { Std. } \\
\text { Deviation }\end{array}$ \\
\hline $\begin{array}{l}\text { Menggunakan } \\
\text { Internet }\end{array}$ & 121,03 & 34 & 16,460 \\
$\begin{array}{l}\text { Tidak Menggunakan } \\
\text { Internet }\end{array}$ & 111,38 & 66 & 18,793 \\
\hline Total & 114,66 & 100 & 18,529 \\
\hline
\end{tabular}

Berdasarkan data pada tabel 1 dapat diketahui bahwa rata-rata kemampuan literasi keluarga pada kelompok keluarga yang menggunakan internet sebesar 121,03, sedangkan rata-rata kemampuan literasi keluarga pada kelompok keluarga yang tidak menggunakan internet sebesar 111,38. Hal ini menunjukkan bahwa rata-rata kemampuan literasi keluarga pada kelompok keluarga yang menggunakan internet lebih tinggi daripada rata-rata literasi keluarga pada kelompok keluarga yang tidak menggunakan internet. Lebih lanjut lagi, rata-rata kemampuan literasi keluarga pada kelompok keluarga yang menggunakan internet lebih tinggi daripada rata-rata kemampuan literasi keluarga pada seluruh responden. Berdasarkan gambar di atas juga dapat dilihat bahwa standar deviasi atau simpangan baku pada data kelompok keluarga yang tidak menggunakan internet lebih tinggi daripada simpangan baku data kelompok keluarga yang menggunakan internet. Dengan demikian dapat disimpulkan bahwa data kelompok keluarga yang tidak menggunakan internet lebih beragam dan dalam rentangan yang lebih panjang.

Pengujian normalitas dilakukan untuk mengetahui apakah data yang akan dianalisis berasal dari populasi yang berdistribusi normal atau tidak. Pengujian normalitas dilakukan dengan uji Lilliefors. Hasil analisis terhadap 100 data diperoleh hasil $\mathrm{L}_{0}=$ 0,0802 sedangkan nilai $\mathrm{L}_{\text {tabel }}$ adalah 0,0886 . Berdasarkan hal tersebut, dapat dilihat bahwa $\mathrm{L}_{0}<\mathrm{L}_{\text {tabel }}$. Sehingga dapat disimpulkan bahwa data literasi keluarga berasal dari populasi yang berdistribusi normal.

Selanjutnya dilakukan uji homogenitas untuk mengetahui keragaman data kedua kelompok yang akan dianalisis. Uji homogenitas yang digunakan adalah uji Bartlett. Perhitungan tersebut menghasilkan nilai $\chi_{\text {hitung }}^{2}=0,7456$, sedangkan $\chi_{\text {tabel }}^{2}$ untuk $\alpha=0,05$ dan derajat bebas 1 adalah 3,8410. Hasil perhitungan menunjukkan bahwa $\chi_{\text {hitung }}^{2}<\chi_{\text {tabel }}^{2}$ sehingga dapat disimpulkan bahwa kedua kelompok data mempunyai varians yang sama, atau dengan kata lain dapat dikatakan bahwa data kedua kelompok adalah homogen. 
Data yang sudah memenuhi asumsi normal dan homogen selanjutnya dianalisis dengan uji perbedaan dua rata-rata untuk sampel bebas. Hasil perhitungan menunjukkan nilai $t_{\text {hitung }}$ sebesar 2,5339, sedangkan nilai $t_{\text {tabel }}$ untuk $a=0,05$ dan derajat bebas 98 adalah 1,6628 . Dengan demikian $t_{\text {hitung }}>t_{\text {tabel }}$ sehingga dapat disimpulkan bahwa terdapat pengaruh penggunaan internet terhadap literasi keluarga. Pengaruh penggunaan internet terhadap literasi keluarga sebesar 6,15\% atau tergolong kecil. Sedangkan pada uji parsial diperoleh hasil bahwa pada kelompok keluarga yang menggunakan internet memiliki literasi keluarga yang lebih baik dibandingkan kelompok keluarga yang tidak menggunakan internet.

Hasil penelitian ini menunjukkan bahwa internet memberikan manfaat bagi masyarakat saat digunakan dengan bijak. Terbukti bahwa pada masyarakat yang menggunakan internet memiliki literasi keluarga yang lebih tinggi. Hal ini sejalan dengan hasil penelitian Soenhaji (dalam Setiyani, 2010) yang menyebutkan bahwa penggunaan internet bermanfaat untuk keberhasilan belajar mahasiswa.

Internet dapat digunakan oleh orang tua dalam mengenalkan huruf, angka, warna, nama-nama binatang, dan lain-lain sejak anak masih batita. Internet juga dapat dijadikan sebagai sumber informasi. Ketika orang tua sulit mendapatkan buku-buku tertentu, kini orang tua dapat mencarinya di internet. Sejalan dengan penelitian yang dilakukan oleh Elian, Lubis, dan Rangkuti (2014) menyebutkan bahwa penggunaan internet menjadi salah satu alternatif ketika tidak memiliki akses terhadap buku, majalah, tabloid, atau bacaan lainnya. Kemudahan teknologi memberikan kemudahan juga pada pencarian buku-buku yang berkualitas dan sesuai yang diinginkan. Internet juga dapat mendorong anak-anak dan orang tua untuk belajar lebih luas. Mengenal dunia yang lebih luas, yang tidak terbatas pada dinding saja. Hal ini sejalan juga dengan hasil penelitian Pibriana dan Ricoida (2017) yang menyebutkan bahwa kemudahan mendapatkan informasi dari internet dapat memotivasi seseorang untuk menumbuhkan minat belajarnya.

Berdasarkan data dimensi pada gambar 1 , terlihat bahwa pada dimensi keterlibatan orang tua memiliki WMS yang paling rendah. Hal ini menunjukkan bahwa responden selaku orang tua belum banyak terlibat pada pendidikan anak-anaknya, seperti menemani anaknya mengunjungi perpustakaan, membacakan cerita, dan lain sebagainya. Orang tua yang melibatkan dirinya pada perolehan pengetahuan anak-anaknya menganggap bahwa hal ini menjadi suatu hal yang penting dan sebaiknya tidak dilewatkan.

\section{PENUTUP}

\section{Kesimpulan Dan Saran}

Berdasarkan analisis data hasil penelitian dapat disimpulkan bahwa kemampuan literasi keluarga pada kelompok keluarga yang menggunakan internet lebih tinggi daripada kemampuan literasi keluarga pada kelompok keluarga yang tidak menggunakan internet. Dengan demikian maka sebaiknya orang tua (terutama ibu) mulai mengenalkan literasi kepada anaknya. Hal itu dapat dilakukan salah satunya melalui penggunaan internet. Penggunaan internet yang bijak dan bertanggung jawab dapat memberikan hasil positif seperti dalam menumbuhkan kemampuan literasi keluarga.

\section{DAFTAR PUSTAKA}

Brooks, G., Kate, P., Pollard, A., \& Rees, F. (2008). Effective and inclusive practices in family literacy, language and numeracy: a review of programmes and practice in the UK and internationally. Shefield: The University of Shefield.

Crawford, PA \& Zygouris-Coe, V. (2006). "All in the family: Connecting home and school with family literacy". Early Childhood Education Journal, 33 (4): 261-267.

Deborah L. (2006). In Pursuit of Knowledge: Scholars, Status, and Academic Culture. Stanford: Stanford Law and Politics.

Desmond, S., \& Elfet, M. (2008). Family Literacy. Cape Town: UNESCO Institute for Lifelong Learning.

Elian, N., Lubis, D. P., \& Rangkuti, P. A. (2014). Penggunaan Internet dan Pemanfaatan Informasi Pertanian oleh Penyulus Pertanian di Kabupaten Bogor Wilayah Barat. Jurnal Komunikasi Pembangunan, 12 (2): 104-109.

Fadriyani, (2010). Keterlibatan Orang Tua Dan Intervensi Guru Dalam Perkembangan Literasi Anak Usia Dini: Studi Kasus Di TK Bhayangkari Kabupaten Bone Propinsi Sulawesi Selatan. Bandung: Universitas Pendidikan Indonesia

Hannon, P. (1999). "Rhetoric and research in family literacy". British Educational Research Jounal, 26 (1): 121-38.

Kim, Y. K. (2010). “The Relationship between Home Literacy Practices and Developmental Trajectories of Emergent Literacy and Conventional Literacy Skills for Korean Children". [Online] Tersedia di: http://citeseerx. ist.psu.edu/viewdoc/download;jsession$\mathrm{id}=583$ F36FE180E247A977AD217EB4CC9BD?- 
doi=10.1.1.617.9362\&rep $=$ rep1\&type $=$ pdf.

Kuo, N. C. (2016). "Promoting Family Literacy Through the Five Pillars of Family and Community Engagement (FACE)". School Community Journal, 2016, Vol. 26 (1).

Laurent, J.g. (2005). “Indicators of Social Quality: Outcomes of the European Scientific". Network. The European Journal of Social Quality, Vol. 5, No. $1 / 2$.

Nickse, R. S., Speicher, A. M., and Buchek, P. C. (1994). An Intergenerational Adult Literacy Project: A Family Intervention/Prevention Model. Adult Literacy: A Compendium of Articles from the Journal of Reading. Newark, DE: International Reading Association.

Pibriana, D. \& Ricoida, D. I. (2017). Analisis Pengaruh Penggunaan Internet terhadap Minat Belajar Mahasiswa (Studi Kasus: Perguruan Tinggi di Kota Palembang). Jurnal Teknik Informatika dan Sistem Informasi, 3 (2): 104-115.
Purcell-Gates, V. (2007). “Family Literacy and Community Literacy". Adult Literacy. Edited by Barbara J. Guzzetti. Praeger Publishers.

Quick, H.E., et al. (2011). Evaluation of the First 5 LA Family Literacy Initiative: Final evaluation report. San Mateo, CA: American Institutes for Research.

Sherlyanita, A. K. \& Rakhmawati, N. A. (2016). Pengaruh dan Pola Aktivitas Penggunaan Internet serta Media Sosial pada Siswa SMPN 52 Surabaya. Journal of Information Systems Engineering and Business Intelligence, 2 (1): 17-22.

Setiyani, R. (2010). Pemanfaatan internet sebagai sumber belajar. Jurnal Pendidikan Ekonomi Dinamika Pendidikan. Vol. V (2), Desember 2010, pp 117-133.

Taylor, D. (1983). Family literacy. Portsmouth, NH: Heinemann.

Wasik, B. H. (2004). Handbook of family literacy. Mahwah, NJ: Lawrence Eribaum Publishes. 